\title{
Отвод земель под крестьянско-фермерское пчеловодческое хозяйство (городской округ Староуткинск, Свердловская область)
}

\author{
Воронова А.В., студентка, \\ Уральский государственный аграрный университет, \\ 2. Екатеринбург \\ E-mail: lena-voronova15@yandex.ru
}

Научный руководитель: к.2.-м.н. Старицына И.А.

Посёлок городского типа Староуткинск находится в Западном управленческом округе Свердловской области, в 6 км от железнодорожной станции Уткинский Завод. Расстояние до города Екатеринбурга составляет 120 км. Территория вокруг городского округа входит в лесопарковую зону [8, с. 252]. Зеленые насаждения представлены в основном хвойными мягколиственными породами. Общий запас спелых и перестойных насаждений составляет 2615000 м $^{3}$. Поселок Староуткинск окружен лесами со всех сторон. Расстояние до лесного массива от 0,5 до 1 км. Преобладают смешанные леса, которые сочетаются с луговой степью. Из кустарников встречаются калина, можжевельник, боярышник, шиповник. Из трав наиболее распространенными видами встречаются клевер, донник, гречиха, одуванчик, мать-и-мачеха, иван-да-чай. Разнообразие медоносных трав и кустарников является благоприятной средой для разведения пчел.

На сегодняшний день в Свердловской области существует около сорока шести тысяч пчелосемей. Крупных медовых ферм нет, но пчеловодством занимаются частники. На юго-западе в Артинском, Красноуфимском и Ачитском районах отрасль развита достаточно хорошо. Здесь располагаются крупные угодья медоносов, поэтому предоставлена хорошая база для кочевого промысла. Частные пасеки работают на территории г. Ирбит, г. Каменск-Уральский, Нижне-Сергинский район.

Рынок продукции пчеловодства состоит в основном из привозного меда, это мед Башкирии, Алтая, Краснодарского края и других регионов России. Средняя цена на мед в регионе составляет:

- Мед Башкирии 450-600 рублей за килограмм;

- Алед 500-600 рублей за килограмм;

- Мед районов Краснодарского края 500-600 рублей за килограмм.

Выбор территории для размещения пасеки в ГО «Староуткинск» обусловлен тем, что на протяжении более 20-ти лет, здесь отсутствует промышленное и другие виды производств, этот населенный пункт находится на расстоянии 60 км от промышленного центра город Первоуральск, что благоприятно для разведения пчел, которые очень зависимы от экологии окружающей среды [3].

На сегодняшний день в Свердловской области действует Постановление Правительства Свердловской области от 17 июля 2012 года №773-ПП «О порядках предоставления грантов на развитие семейных животноводческих ферм, на создание и развитие крестьянского (фермерского) хозяйства и единовременной помощи на бытовое обустройство начинающим фермерам» [4], согласно которому гранты и единовременная помощь оказывается на создание и развитие крестьянских (фермерских) хозяйств в размере до 1 миллиона рублей. Право получения гранта на 
создание и развитие хозяйства, согласно Постановлению, получают те, кто соответствует следующим требованиям:

1. Фермеры, согласно предоставленного бизнес-плана должны оплатить каждую статью расходов собственными средствами не менее, чем 10\% стоимости каждой статьи.

2. Фермерское хозяйство должно соответствовать требованиям Федерального закона от 24 июля 2007 года № 209-Ф3 «О развитии малого и среднего предпринимательства в Российской Федерации» [2].

3. Фермеры должны организовать не менее 1 рабочего места.

4. Фермеры должны израсходовать грант не позднее, чем 12 месяцев со дня поступления денежных средств на расчетный счет.

5. Фермер должен проживать в муниципальном образовании по месту регистрации крестьянско-фермерского хозяйства.

6. Должен осуществлять деятельность не менее пяти лет после получения гранта.

7. Не получал ранее субсидии, гранты.

Были исследованы два земельных участка на предмет оптимальности размещения пчеловодческого хозяйства [7, с. 558]. На основании нормативов расположения построек и ульев на пасеке и планируемого количества ульев, была рассчитана площадь земель, для размещения пчеловодческому крестьянскому (фермерскому) хозяйству [1] в безвозмездное срочное пользование, запланировано на земельном участке 1 в количестве 100 ульев, на земельном участке 2 в количестве 150 ульев [6].

Оптимальной формой обладает землепользование, у которого коэффициент компактности приближается к единице. Коэффициент земельного участка 1 равен 0,99; земельного участка 2 равен 0,86. Таким образом, участок 1 является более оптимальной формой.

Для определения целесообразности размещения пасек на данных участках были изучены преобладающие деревья и кустарники, а также растительность на исследуемых участках [5, с. 66], они были охарактеризованы по наличию насаждений и проанализированы медоносные качества растительности. На участке 1 количество медоносных насаждений составляет 14 (липа, клен остролистый, рябина обыкновенная, василек луговой, вереск обыкновенный, жимолость, черемуха, малина лесная, клевер белый, медуница лекарственная), на участке 2 - 10 (липа, клен остролистый, рябина обыкновенная, василек луговой, ива остролистная шелюга, кульбаба осенняя). Таким образом, земельный участок 1 наиболее благоприятен для размещения пасеки по медоносности растений.

Площадь застройки на участке 1 составляет 51\% от полезной площади участка, площадь застройки участка 2 составляет 44\%. Таким образом, на участке можно поместить большее количество деревьев и медоносных трав, что может увеличить сбор меда.

Объем капитальных вложений для размещения пасеки на участке 1 составил 770649,60 руб. Общая сумма расходов за 5 лет составит 2613968,17 руб. Планируемая прибыль на пятилетнюю перспективу составит 7497686,72 руб.

Объем капитальных вложений для размещения пасеки на участке 2 составил 1185565,40 рублей. Общая сумма расходов на 5 лет составит 4355807,16 руб. Планируемая прибыль на пятилетнюю перспективу составит 9483841,29 руб. 
Рентабельность производства за 5 лет деятельности участка 1 составит 286,8\%, срок окупаемости 1,35 года. У второго участка рентабельность - 217,7\%, срок окупаемости - 4,41 года (таблица 1$)$.

При анализе показателей двух земельных участков приоритет был отдан земельному участку 1. Так как его значение коэффициента компактности наиболее приближено к единице. Это значит, что форма участка оптимальна и имеет форму квадрата, что влияет на расположение ульев, построек, помещений с учетом требований законодательства.

Также участок 1 наиболее удален от населенного пункта. Это создает дополнительную защиту населения от нападения насекомых. Но наиболее приближен, в отличие от земельного участка 2, к дорогам общего пользования и источникам водоснабжения, что достаточно важно для содержания пчел и обеспечения их жизнеспособности.

Таблица 1

Сравнительные показатели земельных участков

\begin{tabular}{|c|c|c|c|}
\hline Показатель & $\begin{array}{c}\text { Единица } \\
\text { измерения }\end{array}$ & $\begin{array}{l}\text { Земельный } \\
\text { участок } 1\end{array}$ & $\begin{array}{r}\text { Земельный } \\
\text { участок } 2\end{array}$ \\
\hline Коэффициент компактности & - & 0,99 & 0,86 \\
\hline Удаленность от населенного пункта & M & 1102 & 686 \\
\hline $\begin{array}{l}\text { Удаленность } \\
\text { пользования }\end{array}$ & M & 919 & 950 \\
\hline $\begin{array}{lcc}\text { Удаленность } & \text { от } & \text { источников } \\
\text { водоснабжения } & & \\
\end{array}$ & M & 655 & 686 \\
\hline Наличие медоносных насаждений & виды & 14 & 10 \\
\hline Объем капитальных вложений, в т.ч. & руб & 770649,60 & 1185565,40 \\
\hline а) Собственные средства & pуб & 77064,96 & 185565,40 \\
\hline б) Инвестиции (грантыл) & руб & 616519,68 & 1000000,00 \\
\hline $\begin{array}{l}\text { Объем текущих расходов на пятилетнюю } \\
\text { перспективу }\end{array}$ & руб & 2613968,17 & 4355807,16 \\
\hline $\begin{array}{l}\text { Выручка от реализации продукции на } \\
\text { пятилетнюю перспективу }\end{array}$ & руб & 10800000,00 & 14445000,00 \\
\hline $\begin{array}{l}\text { Планируемая прибыль на пятилетнюю } \\
\text { перспективу }\end{array}$ & руб & 7497686,73 & 9483841,29 \\
\hline Срок окупаемости вложений & год & 1,35 & 4,41 \\
\hline
\end{tabular}

Участок 1 обладает наиболее богатой медоносной растительностью с более длительным периодом цветения, что является благоприятной средой для разведения пчел. При проектировании были запланированы дополнительные посевы медоносных трав и деревьев таких как гречиха, яблоня, донник, но на период проведения работ и роста насаждений наличие природной растительности дает возможность фермеру качать мед в течение всего медоносного сезона.

При расчете экономических показателей деятельности крестьянского (фермерского) пчеловодческого хозяйства выяснилось, что наиболее выгодным является участок 1. При незначительном объеме капитальных вложений рентабельность производства за 5 лет деятельности составит 202,8\%, срок окупаемости 1,5 года, при том, что у второго участка рентабельность - 155,7\%, срок окупаемости - 
4,41 года. Это говорит о том, что используя средства государственного бюджета на создание крестьянского (фермерского) пчеловодческого хозяйства, фермер должен вложить собственных средств в меньших объемах при организации участка 1 . Наличие собственных средств является немаловажным условием при создании крестьянского (фермерского) пчеловодческого хозяйства и возможностей его реализации. По истечении 1,5 года вся прибыль, полученная от ведения хозяйства, остается в распоряжении членов фермерского хозяйства и может быть направлена на улучшение и развитие производства.

Список литературы:

1. Российская Федерация. Законы. Федеральный закон от 11 июня 2003 года № 74-Ф3 «О крестьянском (фермерском) хозяйстве» [Электронный pecypc]//www.garant.ru.

2. Российская Федерация. Законы. Федеральный закон от 24 июля 2007 года № 209-Ф3 «О развитии малого и среднего предпринимательства в Российской Федерации» [Электронный pecypc]//www.garant.ru.

3. Российская Федерация. Правительство. Ветеринарно-санитарные правила содержания пчел [Электронный ресурс]: Приказ Министерства сельского хозяйства от 15 декабря 1976 года// www.garant.ru.

4. Свердловская область. Правительство. Постановление Правительства Свердловской области от 17 июля 2012 года № 773-ПП «О порядке предоставления грантов на развитие семейных животноводческих ферм, на создание и развитие крестьянских (фермерских) хозяйств и единовременной помощи на бытовое обустройство начинающим фермерам» [Электронный pecypc]//www.garant.ru.

5. Байкин Ю.Л., Иванов Н.А. Н.А., Байкенова Ю.Г., Гусев А.С. Об экологическом мониторинге в системе почва-растения-животные-продукция животноводства. [Текст] // В сборнике: Опыт и проблемы повышения качества молочной продукции, ее конкурентоспособности в рыночных условиях 1997. С. 64-67.

6. Муниципальное образование Городской округ «Староуткинск». Администрация. Правила землепользования и застройки городского округа «Староуткинск» [Электронный ресурс]. - URL: www.staroutkinsk.ru.

7. Старицына И.А., Вашукевич Н.В., Старицына Н.А. Проблемы развития сельскохозяйственных территорий Свердловской области. [Текст] //Островские чтения. 2016. № 1. С. 557-564.

8. Старицына Н.А., Старицына И.А., Вашукевич Н.В. Анализ состояния земельных ресурсов Свердловской области. [Текст] // В сборнике: Уральская горная школа - регионам сборник докладов международной научно-практической конференции. 2016. С. 252-253. 